\title{
Being a mother and a nurse: issues about gender and overlapping social roles*
}

\author{
Ser mãe e enfermeira: questões sobre gênero e a sobreposição de papéis sociais
}

Bruna Caroline Rodrigues ${ }^{1}$, Muriel Fernanda de Lima $^{1}$, Bruno Maschio Neto ${ }^{1}$, Graziela Lopes de Oliveira ${ }^{1}$, Aurea Christina de Paula Corrêa ${ }^{2}$, Ieda Harumi Higarashi ${ }^{1}$

Objective: to describe the experiences of nursing mothers in the reconciliation of their social roles. Methods: this is a qualitative study with 10 nursing mothers. Participants were selected using the snowball method, and through semi-structured interviews. The data were analyzed by the content analysis. Results: the data found led to the configuration of three categories: Learning to be a mother, Reconciling the different social roles: being a mother, wife and professional, and The father as an active participant in raising children. Conclusion: although maternity is considered an important milestone in the life of the subjects, they highlighted the resumption of professional life as a condition for the achievement of self-esteem and better social interaction, even with the emergence of difficulties such as return to work, absence in their families and the configuration of a support network.

Descriptors: Gender Identity; Nursing; Mother-Child Relations; Women’s Health.

Objetivo: descrever as experiências de mães enfermeiras no conciliamento de seus papéis sociais. Métodos: estudo qualitativo, realizado com 10 mães enfermeiras. A seleção das participantes se deu pelo método de bola de neve, e por meio de entrevistas semiestruturadas. Os dados foram analisados a partir da análise de conteúdo. Resultados: os dados encontrados levaram à configuração de três categorias: Aprendendo a ser mãe, Conciliando os diferentes papéis sociais: ser mãe, esposa e profissional e 0 pai como participante ativo na criação dos filhos. Conclusão: apesar de a maternidade ser considerada um marco importante na vida dos sujeitos, estas apontaram a retomada da vida profissional como condição para a conquista da autoestima e do melhor convívio social, mesmo com o surgimento de dificuldades como o retorno ao trabalho, a ausência no seio de suas famílias e a configuração de uma rede de apoio.

Descritores: Identidade de Gênero; Enfermagem; Relações Mãe-Filho; Saúde da Mulher.

\footnotetext{
*Extracted from the dissertation “Mães enfermeiras o processo de cuidado dos filhos no contexto de vida e trabalho", Universidade Estadual de Maringá, 2012.

${ }^{1}$ Universidade Estadual de Maringá. Maringá, PR, Brazil.

${ }^{2}$ Universidade Federal do Mato Grosso. Cuiabá, MT, Brazil.

Corresponding author: Bruna Caroline Rodrigues

Rua Júlio Favoretto, 11, Vila Esperança, CEP: 87020-600. Maringá, PR, Brazil. E-mail: bruninhaamd@hotmail.com
} 


\section{Introduction}

The conception that female people are the protagonists of domestic work, home/family care, and children raising is still very much present in our contemporary society (contemporary Western). In this way, and even if some men are changing their position to be proactive and participative in the life and the family routine, the responsibility regarding the care with the house and the children remains irretrievably associated with the figure of the woman.

In nursing, the representation that the female role is interrelated to the maternal role of promoting care and affection in relationships is still preserved. This fact is directly linked to the conception of "being a mother" as the person who cares, nourishes and educates $^{(1)}$.

In this scenario, it is observed a conjunction of factors that have the sublimation of aspects considered essential for the life of the human being as a consequence. In this perspective, and considering the undeniable association of the female condition with the nursing profession, and the influence that gender issues have on the way of being and doing professional, the present reflection is justified.

Gender issues are historically determined by the concept of feminine and masculine, varying according to time and place. This enables to identify such issues in the most diverse areas of human activity, such as work, education, religion, family relationships, health, politics, among others, and being susceptible to change, by the interventions implemented on the processes that generate them ${ }^{(1-2)}$.

From the Paleolithic era (2 million BC to 10,000 $\mathrm{BC})$, men and women played different social roles. It is a cultural practice that began to delineate gender issues and the roles men and women should play in society. In this context, the woman already saw herself as the family figure responsible for feeding (breastfeeding) her children, making instinctive care an aspect inherent in her being; while for men, it was necessary to leave the shelter in search of hunting for food and subsistence of the group ${ }^{(3)}$.

This configuration or family dynamics has undergone few changes throughout the history of humanity. The greatest transformations were more recently, with the advent of the modern age, having a milestone in the Industrial Revolution regarding the form of insertion and the status of women in society. It was only after the Industrial Revolution that women could envisage the possibility of leaving the private space of their home (home, husband, children), occupying the public space, assuming paid activities in the public area ${ }^{(3)}$.

In this recent trajectory, many changes and achievements have taken place, so today, it is increasingly common to find women occupying positions and performing previously unimaginable functions. Even with the numerous transformations related to the role of women in the family and outside the home, they continue to be the protagonist in raising children $^{(4-5)}$.

In this perspective, the progress and achievements accumulated over the last decades have resulted in the overlapping of tasks and responsibilities, and on not the substitution of the female profile. Traces of this practice and the way of social organization are present, as there are many situations in which the wife continues to assume most of the responsibilities about the care of the home, husband, and children even though she works outside the home ${ }^{(6)}$.

Therefore, it is no coincidence that there is a change in the health profile of the current woman, who has come to be affected by a stressful lifestyle in large part, before exclusive to men as the main providers of the home.

On the shoulders of the modern woman, there is the responsibility of being competent professionals and able to work in the labor market, along with other culturally constructed attributions, which include the home administration, the home care, the husband, as well as the central role in the process of education and 
parenting. Thus, this study aimed to describe the experiences of nursing mothers in the reconciliation of their social roles.

\section{Methods}

It is a qualitative study, carried out with 10 single-parent nursing mothers and working professionals. Women with preschool children were included in this study, so that it was possible to highlight the more detailed description of their experiences in the care process in their testimonies, from birth to the current situation. Also, mothers with only one child were chosen so that references to the experience of motherhood could be duly isolated and referenced more accurately.

The participants were selected by intentional sampling. For sample extension, the chain or snowball $\operatorname{method}^{(7)}$ was used to choose the mothers.

The data collection took place from November 2011 to January 2012 through interviews recorded and guided by a semi-structured script. The script was composed of topics aimed at the characterization of the participants and open questions about the experience of mothers in the care of their children and relationships with their work. The data were collected without pre-determination of the number of mothers since the number of individuals was determined by the data saturation and scope of the proposed objective.

Before the use of the data collection instrument, the script was evaluated by a group of experts in the theme, composed of three research teachers, one of the Child Health area, one of Women's Health and one of the Family area, so the questions were pertinent to the purpose of the study.

The interviews were in Maringá, Paraná, at the home of each participant or their place of work, according to the preference of each person, and there was an average duration of 40 minutes.

Subsequently, the reports were transcribed and organized from the content analysis technique, which follows three stages: pre-analysis, material exploration, and treatment of results. These stages were aimed at finding the sense nuclei of each participant's speeches to concretize the thematic categorization ${ }^{(8)}$. The guiding question giving rise to the categories was: What was it like to become a mother and reconcile the roles of wife, housewife and working woman? Participants were identified with letter $\mathrm{E}$ and Arabic numerals after the interview.

The study complied with the formal requirements contained in the national and international regulatory standards for research involving human beings.

\section{Results}

There were 10 nursing mothers aged between 29 and 46 years old participating in this study. Six of them were married, two were in stable unions, and two were divorced. The age of the mothers at the time of the child's birth varied between 25 and 39 years old (average of 30 years old). Regarding the educational level, all the interviewees had at least one postgraduate degree in the Lato Sensu modality. The monthly family income ranged from $R \$ 1,800.00$ to $R \$$ $15,000.00$. In most families, two people contributed to this income. In five of the families, the husband was appointed as the largest contributor.

Regarding the age and gender of the children, the first one varied from eight months to six years old, with a fair distribution between the genders. Only three couples did not plan for gestation. The most cited reason by mothers for choosing to become pregnant was financial and professional stability. Regarding the baby's age at the time of the mother's return to employment, they varied between three and nine months.

The exclusive breastfeeding period ranged from four to six months, with supplemented breastfeeding varying from four to 28 months. Only three mothers exclusively breastfed until the sixth month of the child's birth. When questioned about the reason for 
their early introduction of food, most of them pointed to their return to work. There were mothers who also reported reduction and cessation of milk production at four months, even with the use of stimulant drugs.

From the process of analyzing the reports concerning the central problem of the study, that is the overlapping of social roles experienced by nursing mothers, and the influence of gender issues in this context, three thematic categories emerged: Learning to be a mother, Reconciling the different social roles: being a mother, wife and professional, and The father as an active participant in raising the children.

\section{Learning to be a mother}

The start of this new social role in the life of woman represented by motherhood was described by the study participants as an important milestone in their lives, combining the sense of deep personal fulfillment associated with the feeling of unconditional love. I thought like this: I am working, doing everything I want, but something is missing in my life. When a child is born, everything is different. It is an unconditional love (E2). You take responsibility with a human being who depends on you, both of health and development; your child teaches you to be a mother. It is an exchange of knowledge. So, we only feel complete when we become mothers (E4).

The speeches presented show the mothers reporting changes in their lives after the birth of a child. However, despite the responsibility and the numerous tasks, feelings of gratification and personal fulfillment were reported spontaneously.

Mothers mentioned the decision to become pregnant only after the financial and professional stability of the couple: I always wanted to be a mother... I believe I was the right age, because I already had my job, my specializations... I waited for the ideal moment to be able to care more and be more present (E6). I waited to get some stability, he (husband) went on a public tender, I also earned reasonably well... we bought a house, and then I got pregnant (E9).

The option for more flexible hours adaptable to new demands and family routines could be noted in this speech: When I chose to get pregnant I gave up many things: work at night, for example, but I had that option. We know that there are nurses who do more than 40 hours a week and end up distancing themselves from their children (E2).

\section{Reconciling the different social roles: being a mother, wife and professional}

This thematic category is about the difficulties experienced by nursing mothers in leading with their social roles, as mothers, wives, and professionals. The participants' reports show the presence of a crisis of roles in the lives of these women, generated by the pressure on their adequate performance in fulfilling these multiple functions. When she decided to have financial independence, she had to choose to have this triple burden: to be a professional, to be a mother and to be a wife. It is a difficult task! I am here, but I am thinking and articulating some things at home, always organizing the day better (E5). I still do not evaluate very well my role as a nurse/mother... because I take my daughter to school to be able to perfect myself as a nurse (E6).

Also, the interviewees pointed out their absence within their families as a situation that generates tension. These gaps are mainly related to the performance of the maternal role and perceived by the mothers in terms of their children's behaviors and attitudes, including crying or even in episodes of illnesses that denoted the insufficiency of attention: Sometimes, she (daughter) asks to stay with me or do things to get my attention. I believe she misses me (E1).

The absence of the partner appeared in the speeches of two participants, as a factor of aggravation of the overload of the mother-nurse role. Thus, the need to respond to the household allowance and perceive the education and care of the child as a solitary mission has made reconciling responsibilities more challenging: I do not feel guilty that my daughter has gone to school early because I know I am the only one responsible for her livelihood and that for her to be happy, I have to be happy too (E4). From the moment I decided to have a child, I have to know how to reconcile my things, not to dedicate exclusively to work, but I cannot afford to dedicate exclusively to it because I will be sustained by my work (E9). 
In this perspective, and even though they valued the mother and child relationship as a unique opportunity for exchanges, and as the main source of happiness in their lives, the participants revealed the importance of professional activity in their projects of personal fulfillment. In this process, the delegation of care assignments to third parties ended up as a condition for achieving these goals, setting up as another challenge: We do not think anyone will know how to care for us, neither the school nor the mother because you do not trust, you want to be close, you want to be seeing (E3). Fear of hurting, of not being near, afraid of her. I called the school all day (E4).

Despite the initial feelings of insecurity when delegating care, some women affirmed the resumption of professional life as a condition for the achievement of self-esteem and better social interaction. As much as I enjoy being a mom, staying home all the time made me feel alienated from the world. I was my job missing a lot (E1). I liked it because I went back to work, I came back to feel useful, I stopped being the domestic utensil to be a person again, and I felt good because I was disconnected from it... I rested a little on the relation mother and daughter (E4).

It is noteworthy that even with constant concern for the well-being of children, women needed to act professionally to feel complete. In this sense, it can be said that today's children who grow up and become mothers are already accustomed to this new model of life.

Regarding the roles of wife and housewife, some mothers considered that they did not perform their duties properly. The role of wife is what I least care... we had situations where we spent almost a month without sleeping at the same time... so I end up distancing myself a lot from him (husband) (E1). As for the housewife, I am very much in debt; I could not trace a routine... if I am at home, I am taking care of my daughter. The role of "housewife" I always leave it to later... I cannot reconcile (E4).

\section{The father as an active participant in raising the children}

In this study, the father's participation in child raising was described as very effective and essential for several women interviewed: Excellent... he helps me care about her in education, she often respects her father more than me. He is stiffer, firmer. I cannot complain about anything (E6). He participates a lot. When we chose to have a child, we decided that we would be father and mother. We are only going to have one job each (E8).

Paradoxically, the help and participation in raising the children proved to be exclusive of the men in the situation of marriage or stable union. This finding raises the perception that responsible and participatory parenting is linked to the maintenance of marital commitment, dissolving when the marriage of the couple comes to an end.

In this way, the absence of the father figure in the families of separated parents was shown as: He was present and contributed a lot... besides the care of hygiene and food, he also took care of playing, to be present. He contributed a lot, but after the separation, I cannot evaluate him because he is not present (E4).

\section{Discussion}

From the testimonies, it was possible to see that maternal love can sometimes be configured as a process of construction, not always idealized a priori, as a life goal of all women ${ }^{(9)}$. The maternal feeling is uncertain, fragile, and imperfect, and it is not necessarily tied to the female nature. Although this idea is currently recognized, people still believe that the mother's love for her child is instinctive.

In this perspective, gestation and motherhood may emerge as a belated necessity, at a later stage of human living conditioned by the stability and consolidation of conquests in the other sectors of the person's life. Thus, besides the professional and personal success, motherhood can emerge as a gap to be filled for the full realization of the female being.

In this study, even with a planned pregnancy and as claimed by some mothers, the process of family adjustment and adaptation to this new reality may represent a moment of crisis or stress for the couple, aggravated by social pressures and increased respon- 
sibilities to this new human being, who depends entirely on the care and affection offered by his parents. The prior elaboration of this phase, in a more propitious moment from the professional and economic point of view for the couple, can soften the difficulties of adequacy ${ }^{(10)}$.

Although family planning has been referred by many nursing mothers as reflecting a differentiated socioeconomic and cultural profile, and despite the fact that pregnancy was chosen due to the choice of the most suitable time for the arrival of a child, this fact did not exempt the participants of the need to resort to family and professional assistance in the process of caring and educating their children, especially on their return to the labor market after maternity leave. It is observed that the phenomenon of outsourcing of child care is not exclusive to less favored classes, but it reflects a transformation of the productive society, and the pressures that it generates over the people inserted into it ${ }^{(11)}$.

Ultimately, such context causes the child to become a victim of the work overload assumed by the mother according to the level of physical and psychoactive dependence they carry. This "'absence" of parents in child-raising is becoming more common, resulting in a variety of behavioral and educational repercussions among children ${ }^{(5)}$.

The concept of care ${ }^{(12)}$, especially of father and mother, has been lost over time, leading people to the question of who is responsible for their children. Most of the time, the nanny plays the role of father and mother, to stay longer with the child and the feelings of love and care generated from this relationship. It is necessary to rethink the family composition, the quality of the relationships between its members and the time dedicated to the children.

In the nursing profession, some characteristics inherent to the traditional figure of the woman, represented by her vocation for affective care, are transported to her professional work. Many of the components of the way of relating and of the feminine way of being are mentioned in this professional work, which causes the sensitivity and personal involvement with the suffering of others to emerge within the scope of their professional performance, exacerbating the psycho-emotional overload of these women.

The mothers' difficulty in reconciling roles emerged in the testimonies of the participants of this study, corroborating with findings in the literature ${ }^{(13-14)}$. Insecurity and fear were hallucinating feelings for nursing mothers who delegate child care to others, such as institutions, babysitters or even family members. However, the reports showed these anxieties as aspects that permeate the initial phase of the process of separation of the child and the mother, in their return to the labor market, and until the relationship of trust is established between the mothers and the caregivers of their children.

Regarding the father's participation in child raising, a positive evaluation was obtained in the process of child raising, reflecting a phenomenon of transformation of social relationships, and a reconfiguration of the roles that men and women occupy in today's society. In this way, the father figure, as a distant being of his family, essentially with the task of providing the material necessities of the house, gives place to a father who is more participatory and integrated with the family dynamics ${ }^{(15)}$.

Although the father is an incomplete figure in the function of caring for the child in the first years of life, due to biological, psychic and philosophical factors $^{(11)}$, and having his image historically linked to the economic provision of the family, paternal presence is fundamental for the creation of the bond with the child and mainly supporting the mother ${ }^{(16-17)}$.

The separation from the couple reveals another aspect inherent in the issue of the feminine gender and motherhood, and the feeling of accountability and indelible bond that this condition brings to the female being. Thus, paternity and maternity appear as conditions that are established simultaneously, but with quite distinct implications and intensities, and with the expectations and requirements inherent to the exercise of these two roles in our society and culture. 
The limitations of the research are related to the small number of subjects, not allowing the generalization of the results to other realities. The study induces a reflection on the maternal function, in its relationships with the work context, highlighting the difficulties experienced by the nurses to achieve the dream of being mothers, as opposed to their demands and the ideal of nursing care.

\section{Conclusion}

It is concluded that at the same time as the nurse woman seeks the fulfillment of her happiness through a series of achievements, such as marriage, children and the constitution of a structured family, other elements and demands emerged as the fruits of a new insertion of women in society. The mothers pointed to the resumption of professional life as a condition for the achievement of self-esteem and better social interaction, even with the emergence of difficulties after the birth of children such as return to work, their absence in their families and need to set up a support network.

The overlapping of innumerable roles and internal and external pressures, in search of a supposed perfection in their performance, directly affects the quality of life and health of these professionals, as well as the process of caring and educating their children. In this scenario, it is necessary to recognize the limits inherent in the human being, providing these working women who lead their personal and professional life without prejudice to their physical and mental well-being.

\section{Collaborations}

Rodrigues BC contributed to the project design, data collection, analysis and interpretation, article writing and final approval of the version to be published. Lima MF contributed to data collection, organi- zation, and interpretation of the data and writing of the article. Maschio Neto B and Corrêa ACP contributed to the analysis of the data and final approval of the version to be published. Oliveira GL and Higarashi IH contributed to the project design, article writing and final approval of the version to be published.

\section{References}

1. Souza LL, Araújo DB, Silva DS, Bêrredo VCM. Representações de gênero na prática de enfermagem na perspectiva de estudantes. Cienc Cogn. 2014; 19(2):218-32.

2. Almeida DB, Queirós PJP, Silva GTR, Laitano ADC, Almeida SS. Estereótipos sexistas na enfermagem portuguesa: Um estudo histórico no período de 1935 a 1974. Esc Anna Nery. 2016; 20(2):228-35.

3. Teixeira MS. Perfil da mulher no mercado de trabalho. Rev Psicol. 2012; 17(1):95-123.

4. Verza F, Sattler MK, Strey MN. Mãe, mulher e chefe de família: perspectivas de gênero na terapia familiar. Pensando Fam. 2015; 19(1):46-60.

5. Martins Filho J. Quem cuidará das crianças? A difícil tarefa de educar os filhos hoje. Campinas (SP): Papirus; 2011.

6. Fiorin PC, Oliveira CTD, Dias ACG. Percepções de mulheres sobre a relação entre trabalho e maternidade. Rev Bras Orientac Prof. 2014; 15(1):25-35.

7. Heckathorn DD. Snowball versus respondentdriven sampling. Sociol Methodol. 2011; 41(1):355-66.

8. Bardin L. Análise de conteúdo. Lisboa: Edições 70; 2011.

9. Shreffler KM, Greil AL, Mitchell KS, McQuillan J. Variation in pregnancy intendedness across US women's pregnancies. Matern Child Health J. 2015; 19(5):932-38.

10. Borges ALV, Santos OA, Nascimento NC, Chofakian CBN, Gomes-Sponholz FA. Preconception health behaviors associated with pregnancy planning status among Brazilian women. Rev Esc Enferm USP. 2016; 50(2):208-16. 
11. Martins Filho J. A criança terceirizada: Os descaminhos das relações familiares no mundo contemporâneo. Campinas: Papirus; 2010.

12. Capelatto I, Martins Filho J. Cuidado, afeto e limites: uma combinação possível. Campinas: Papirus 7 Mares; 2010.

13. Martins CA, Abreu WJCP, Figueiredo MCAB. O sofrimento do regresso ao trabalho após a licença parental. Rev Port Enferm Saúde Mental. 2015; (n.spe):69-77.

14. Andrade LMC, Martins MMFPS, Angelo M, Santos ATVMF, Martini JG. Identifying the effects of children on family relationships. Acta Paul Enferm. 2014; 27(4):385-91.
15. Menezes M, Moré CLOO, Barros L. Social networking Family of caregivers during hospitalization of children. Rev Esc Enferm USP. 2016; 50(n.esp):107-13.

16. Ferreira IS, Fernandes AFC, Lô KKR, Melo TP, Gomes AMF, Andrade IS. Perceptions of pregnant women about the role of partners in prenatal consultations. Rev Rene. 2016; 17(3):318-23.

17. Ferreira FH, Wernet M, Marski BSL, Ferreira GI, Toledo LPN, Fabbro MRC. Paternal experience during the child's first year of life: integrative review of qualitative research. Rev Eletr Enf [Internet]. 2015 [cited 2016 Apr 12]; 17(3):1-12. Available from: https://www.fen.ufg.br/revista/ v17/n3/pdf/v17n3a21-en.pdf 